Cowan, S. T. (1953). J. gen. Microbiol. 9, 101-109.

\title{
Micromethod for the Methyl Red Test
}

\author{
By S. T. COWAN \\ National Collection of Type Cultures, Colindale Avenue, \\ London, N.W. 9
}

\begin{abstract}
SUMMARY: A micromethod for the methyl red (MR) test was worked out for suspensions of bacterial cells. The most important factors in the test are (1) the density of the cell suspension; (2) the ratio of glucose to buffer concentrations. Adaptation of the cells to glucose is essential for the success of the test, and cells from glucose-free media are not satisfactory. At the optimal glucose : buffer ratio Bacterium coli and Klebsiella aerogenes suspensions have different effects on the final pH value attained in the system.

Because the Mr microtest is dependent on a fine balance between glucose and buffer concentrations, and is so greatly affected by even twofold differences in cell concentration, it is not really suitable for routine work in the characterization of bacteria.
\end{abstract}

The methyl red (MR) test was developed by Clark \& Lubs (1915) who rather optimistically said that 'Simple conditions have been found under which metabolism can be so controlled that the hydrogen ion concentrations of cultures of one group can be made to diverge widely from those of the other group' (p. 173). The test measures the final acidity of a culture in a buffered medium containing glucose and peptone, but the $\mathrm{pH}$ value recorded at the time of the test is not necessarily the lowest value attained during growth. In the early stages of glucose fermentation sufficient acid is produced by both Bacterium coli and Klebsiella aerogenes (syn. Bact. aerogenes, Aerobacter aerogenes) to turn methyl red indicator orange or red (MR-positive), but on further incubation $K$. aerogenes breaks down the pyruvic and other acids, and produces a reversion in the reaction of the culture towards neutrality; methyl red indicator becomes yellow (MR-negative). The timing of this sequence,

$$
\text { starting pH (c. 7) } \rightarrow \text { low pH (c. 5) } \rightarrow \text { higher pH (6 or more), }
$$

will be affected by the medium, particularly the buffering power of the peptone and phosphate, by the temperature and duration of incubation, and by the strain. It is surprising, therefore, that a greater attempt has not been made to standardize the test.

At first sight it did not appear that the MR test could be fitted into the range of microtests on suspensions developed by Clarke \& Cowan (1952). In cultures growing in a complex medium such as glucose phosphate peptone broth, more than one enzyme system will be in action and each may have some effect on the $\mathrm{pH}$ value of the culture; in particular $\mathrm{NH}_{3}$ production from peptone can be expected to prevent the development of an extremely low pH value. On the other hand, in living but non-multiplying (static) suspensions, glucose fermentation has a simpler effect on the $\mathrm{pH}$ value; the 
introduction of phosphate buffer slows the initial fall and may prevent the ultimate inactivation of the enzyme system. Contrary to expectation, a workable MR microtest was developed from the modified fermentation method (Cowan, 1953).

\section{MATERIALS AND METHODS}

Strains. Classical strains of Bact. coli, including Escherich's original strain (NCTC 86), and of $K$. aerogenes, including two reputed descendants of Pfeiffer's Bacillus capsulatus (NCTC 243 and 418), were supplemented by other well-authenticated strains from Dr E. Windle Taylor of the Metropolitan Water Board's laboratory, various serotypes of the Escherichia and Klebsiella groups from Dr F. Kauffmann, strains from Dr T. Richards of Reading University, and a series of coliform bacteria collected for another purpose.

Media. The basal medium (LA) had the following composition: Lemco $1 \%$, $\mathrm{NaCl} \mathbf{0 . 5} \%$, Evans peptone 1\%, New Zealand agar 1\%; pH 7.6. Glucose agar (GA) was LA + $1 \%$ glucose.

Cultures. Except where stated otherwise, cultures were grown for 18-22 hr. at $30^{\circ}$ on GA.

Suspensions. Cultures were washed off solid medium into sterile distilled water, centrifuged and the deposit resuspended in distilled water.

Buffer. Sørensen's phosphate buffer, $\mathrm{pH}$ 6.8, was used at various molar concentrations.

Indicators. Methyl red (0.04\%) and bromcresol purple $(0.04 \%)$ were made up in $98 \%$ ethanol.

Methyl red (MR) test. Tests were made in $65 \times 10 \mathrm{~mm}$. tubes, to which were added $0.5 \mathrm{ml}$. phosphate buffer $\mathrm{pH} 6.8,0.05 \mathrm{ml}$. glucose, and $0.05 \mathrm{ml}$. suspension. Concentrations of buffer, glucose and cell suspension varied in different experiments. Except where stated, the mixtures were kept at $37^{\circ}$ (water-bath), and at intervals tubes were removed for test; to these 0.06$0.08 \mathrm{ml}$. methyl red solution was added, the tubes shaken and the colours compared with a standard. In many experiments duplicate sets were made, and to each tube of one set $0.025 \mathrm{ml}$. bromcresol purple was added, and $\mathrm{pH}$ values were read at intervals. Capillator sets of standards (British Drug Houses, Ltd., London) for methyl red and bromcresol purple were used for experiments in which the result was expressed as a pH value.

\section{RESULTS}

\section{Change in $\mathrm{pH}$ value during glucose fermentation}

In the fermentation of glucose by Bact. coli suspensions there was a progressive increase in acidity and fall in $\mathrm{pH}$ value; on the other hand, with $K$. aerogenes there was a quicker initial fall in $\mathrm{pH}$, and later a gradual reversal of reaction, presumably because of the breakdown of pyruvic acid. Table 1 shows the results of an experiment in which $0.1 \mathrm{M}$-glucose was fermented in the presence of $0.025 \mathrm{M}$-phosphate buffer, $\mathrm{pH} \mathrm{6.8}$. Within the first hour $K$. aerogenes had lowered the pH much more than had Bact. coli, but after the second hour the reversal of reaction was apparent. From this experiment it is seen that the 
changes in $\mathrm{pH}$ value closely parallel those of cultures growing in glucose phosphate peptone broth. Translated into terms of the MR test a reaction of pH 5.0 or less is MR,+ 5.8 or above is $M R-$, and values between 5.0 and $5 \cdot 8$ are $M R \pm$ or doubtful. With a doubtful range extending so widely it may be advisable to use bromcresol purple to supplement the information given by methyl red.

Table 1. Changes in pH value during the breakdoren of glucose by Bacterium coli and Klebsiella aerogenes suspensions 0.025 M-buffer, pH 6.8, 0.5 ml.; 0.1 M-glucose, $0.05 \mathrm{ml}$; suspension, 0.05 ml.

$\begin{array}{ccc}\begin{array}{c}\text { Time } \\ \text { (hr.) }\end{array} & \begin{array}{c}\text { Bact. coli } \\ \text { (NCTC 86) } \\ \text { pH values }\end{array} \\ 0 & 6 \cdot 8 & \begin{array}{c}\text { K. aerogenes } \\ \text { (NCTC 243) }\end{array} \\ 1 & 6 \cdot 0 & 5 \cdot 8 \\ 2 & 5 \cdot 4 & 5 \cdot 4 \\ 3 & 5 \cdot 4 & 5 \cdot 8 \\ 4 & 5 \cdot 2 & 5 \cdot 8 \\ 6 & 5 \cdot 4 & 6 \cdot 0 \\ 24 & 4 \cdot 8 & 6 \cdot 0\end{array}$

Importance of buffer in test

Bact. coli (NCTC 8169) and $K$. aerogenes (NCTC 8348) were grown on LA and GA and suspensions were made from each culture. Suspensions were added to $0 \cdot 1 \mathrm{M}$-glucose and diluting fluid which, in three cases was phosphate buffer pH 6.8, and in the fourth was distilled water. Hourly tests up to $6 \mathrm{hr}$. and at $24 \mathrm{hr}$. made by the addition of methyl red showed (Table 2 ) that both strains were always MR-positive $(M R+)$ when water was the diluent and

Table 2. Effect of growth medium, buffer concentration and duration of incubation on methyl red microtest

Buffer pH 6.8, or water, 0.5 ml.; 0.1 M-glucose, 0.05 ml.; suspension, 0.04 ml.

Incubation at $37^{\circ}$

\begin{tabular}{|c|c|c|c|c|c|c|c|c|c|c|c|c|c|c|c|}
\hline \multirow[b]{4}{*}{ Strain } & \multirow{4}{*}{$\begin{array}{c}\text { Buffer } \\
\text { concen- } \\
\text { tration } \\
\text { (M) }\end{array}$} & \multicolumn{13}{|c|}{ Suspension from growth on } & \\
\hline & & \multicolumn{7}{|c|}{$\mathbf{L A}$} & \multicolumn{7}{|c|}{ GA } \\
\hline & & \multicolumn{14}{|c|}{ Time of reading (hr.) } \\
\hline & & 1 & 2 & $\mathbf{3}$ & 4 & 5 & 6 & 24 & $\mathbf{I}$ & 2 & $\mathbf{3}$ & 4 & 5 & 6 & $\mathbf{2 4}$ \\
\hline $\begin{array}{c}\text { NCTC 8169, } \\
\text { Bact. coli }\end{array}$ & $\begin{array}{l}0.07 \\
0.025 \\
0.01 \\
\text { Water }\end{array}$ & $\begin{array}{l}- \\
\bar{t} \\
+\end{array}$ & $\begin{array}{l}- \\
\pm \\
+\end{array}$ & $\begin{array}{l}- \\
+ \\
+ \\
+\end{array}$ & $\begin{array}{l}- \\
+ \\
+ \\
+\end{array}$ & $\begin{array}{l}- \\
+ \\
+ \\
+\end{array}$ & $\begin{array}{l}- \\
+ \\
+ \\
+\end{array}$ & $\begin{array}{l}- \\
+ \\
+\end{array}$ & $\begin{array}{l}- \\
\pm \\
+ \\
+\end{array}$ & $\begin{array}{l}- \\
+ \\
+ \\
+\end{array}$ & $\begin{array}{l}- \\
+ \\
+ \\
+\end{array}$ & $\begin{array}{l}- \\
+ \\
+ \\
+\end{array}$ & $\begin{array}{l}- \\
+ \\
+ \\
+\end{array}$ & $\begin{array}{l}- \\
+ \\
+ \\
+\end{array}$ & $\begin{array}{l}- \\
+ \\
+ \\
+\end{array}$ \\
\hline $\begin{array}{l}\text { NCTC 8348, } \\
\text { K. aerogenes }\end{array}$ & $\begin{array}{l}0.07 \\
0.025 \\
0.01 \\
\text { Water }\end{array}$ & $\begin{array}{l}- \\
\bar{t} \\
+\end{array}$ & $\begin{array}{l}- \\
\pm \\
+ \\
+\end{array}$ & $\begin{array}{l}- \\
+ \\
+ \\
+\end{array}$ & $\begin{array}{l}- \\
+ \\
+ \\
+\end{array}$ & $\begin{array}{l}- \\
+ \\
+ \\
+\end{array}$ & $\begin{array}{l}- \\
+ \\
+ \\
+\end{array}$ & $\begin{array}{l}- \\
+ \\
+ \\
+\end{array}$ & $\begin{array}{l}- \\
\pm \\
+ \\
+\end{array}$ & $\begin{array}{l}- \\
\pm \\
+ \\
+\end{array}$ & $\begin{array}{l}- \\
\bar{t} \\
+\end{array}$ & $\begin{array}{l}- \\
\bar{t} \\
+\end{array}$ & $\begin{array}{l}- \\
\pm \\
+\end{array}$ & $\begin{array}{l}- \\
\pm \\
t\end{array}$ & $\begin{array}{l}- \\
- \\
+\end{array}$ \\
\hline
\end{tabular}


MR-negative (MR - ) with strong buffer (0.07 M); that the distinction between the strains was only seen in suspensions made from growth on GA; and that it was best seen in buffer at 0.025 concentration, and after $24 \mathrm{hr}$. incubation.

Table 3. Effect of suspension concentration and volume of $0 \cdot 1 \mathrm{M}-\mathrm{glucose}$ in the test

0.025 M-phosphate buffer, pH 6.8, 0.5 ml.; 0.1 M-glucose, 0.04-0.06 ml.; suspension 0.05 ml.

\begin{tabular}{|c|c|c|c|c|}
\hline \multirow[b]{2}{*}{ Strain } & \multirow{2}{*}{$\begin{array}{c}\text { Suspension } \\
\times 10^{\natural} / \mathrm{ml}\end{array}$} & \multicolumn{3}{|c|}{$0 \cdot 1 \mathrm{~m}$-glucose } \\
\hline & & $0.04 \mathrm{ml}$. & $0.05 \mathrm{ml}$. & $0.06 \mathrm{ml}$. \\
\hline \multirow[t]{4}{*}{ NCTC 86, Bact. coli } & 16 & - & + & + \\
\hline & 8 & - & + & + \\
\hline & 4 & - & + & + \\
\hline & 2 & - & - & - \\
\hline \multirow[t]{4}{*}{ NCTC $243, K$. aerogenes } & 16 & - & - & - \\
\hline & 8 & - & - & - \\
\hline & 4 & - & - & - \\
\hline & $\mathbf{2}$ & - & - & \pm \\
\hline
\end{tabular}

$+=\mathrm{pH} 5.0$ or less; $\pm=\mathrm{pH}$ c. $5 \cdot 6 ;-=5.8$ or more. Readings after $24 \mathrm{hr}$. at $37^{\circ}$.

Other preliminary experiments showed that, at one buffer concentration, the result was influenced by suspension concentration and by the volume of 0.1 M-glucose added (Table 3 ). It became clear that in the application of the test to routine work, roughly calibrated pipettes, adequate for the other microtests, would not be reliable and that correctly graded pipettes were . essential.

\section{Relation between glucose and buffer concentrations}

Phosphate buffer, pH 6.8, was kept at a constant volume of $0.5 \mathrm{ml}$, glucose at $0.05 \mathrm{ml}$., and suspension at $0.05 \mathrm{ml}$., and the concentrations were varied. The general plan was to set up the experiment in duplicate; bromcresol purple was added as an internal indicator to one set and readings were taken at intervals by comparing the colour with the capillator colour card for that indicator. After $24 \mathrm{hr}$. methyl red was added to the second set and the colours matched against the appropriate capillator card. In the range in which the indicators overlapped, the readings were averaged.

In most experiments the suspension was kept constant and both the buffer and glucose concentrations were varied, in a few experiments all three were varied (Table 4). When the suspension is constant and is at least equivalent in density to $8 \times 10^{\circ} \mathrm{Bact}$. coli $/ \mathrm{ml}$, there is a ratio of glucose : buffer concentrations at which the distinction between Bact. coli and $K$. aerogenes can be seen. When glucose is proportionately greater both species produce more acid and are indistinguishable; proportionately more buffer again masks the differences. The optimal glucose : buffer ratio generally holds good between 0.1 and $0.8 \mathrm{M}$-glucose and 0.025 and $0.2 \mathrm{M}$-phosphate buffer; ignoring the difference in volumes and expressing the ratio in terms of molar concentrations, it is $4: 1$; when allowance is made for the difference in volume the optimal proportion 
is $4:$ 10. Below $0 \cdot 1 \mathrm{~m}$-glucose this ratio does not hold, and even at $0.1 \mathrm{M}$ glucose an occasional strain will show an anomalous result.

When the suspension density is less than $8 \times 10^{\circ} \mathrm{Bact}$. coli $/ \mathrm{ml}$. the distinction between Bact. coli and $K$. aerogenes is lost, even at the optimal glucose : buffer ratio.

Table 4. Experiment to show relation between concentrations of glucose and buffer, and the effect of suspension concentration

Buffer pH 6.8, 0.5 ml.; glucose solution, 0.05 ml.; suspension, $0.05 \mathrm{ml}$.

Test read after $24 \mathrm{hr}$. at $37^{\circ}$

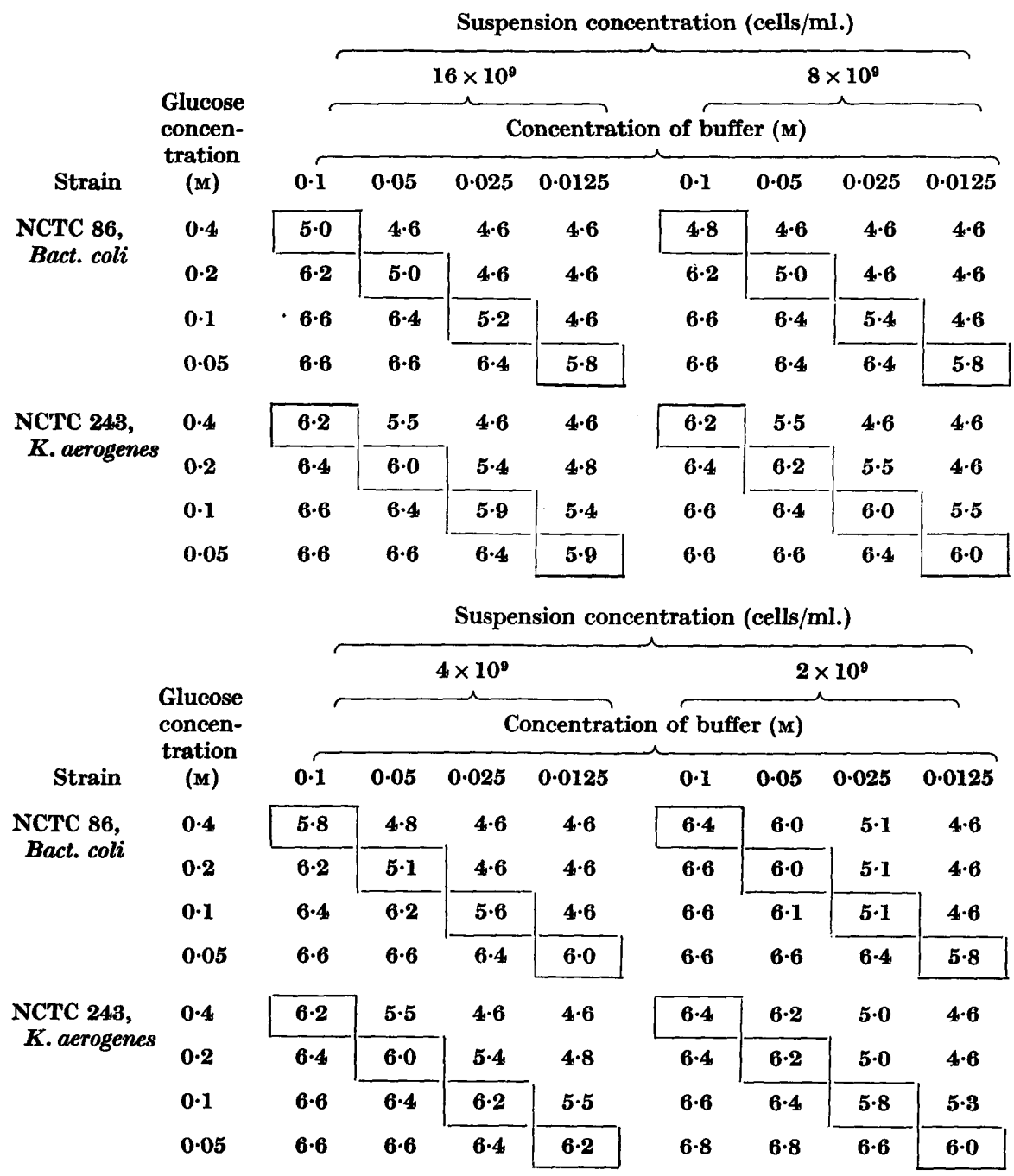

pH values estimated with methyl red and bromcresol purple; a mean was taken in the range of overlap.

Squared figures have the same glucose : buffer ratio. 


\section{Effect of temperature}

Cultures were grown at $\mathbf{3 0}$ and $37^{\circ}$, and suspensions made from each were tested in water-baths at 30 and $37^{\circ}$. The temperature of the test had little effect on the final $\mathrm{pH}$ value attained in $24 \mathrm{hr}$. at the optimal glucose : buffer ratio, but the temperature at which the culture had been grown occasionally had some influence.

Some strains, such as NCTC 8835 , when grown at $30^{\circ}$ yielded suspensions which produced a $\mathrm{pH}$ of about $6.0(\mathrm{MR}-)$ and when grown at $37^{\circ}$ the suspensions produced a $\mathrm{pH}$ of $\mathbf{5 \cdot 2 - 5 \cdot 8}$, that is in the MR doubtful range. Other strains grown at the two temperatures yielded suspensions that hardly differed from each other; any effect was a slightly lower $\mathrm{pH}$ from cultures grown at $37^{\circ}$. What differences there are seem to relate to the optimal temperature for growth which, for most coliforms, is nearer $30^{\circ}$ than $37^{\circ}$.

\section{Effect of growth medium}

Adaptation of the cells to glucose seems to be a prerequisite for the MR microtest; without such adaptation, as with suspensions from growth on LA, $K$. aerogenes remained MR + (Table 2). The effect of different carbohydrates was compared by growing Bact. coli and $\boldsymbol{K}$. aerogenes on LA + glucose, lactose, maltose or mannitol, and preparing suspensions from the resulting growths. In the microtest made at different glucose and buffer concentrations, $K$. aerogenes suspensions from $\mathrm{LA}+$ glucose produced a $\mathrm{pH}$ of 6.2 (i.e. $\mathrm{MR}-$ ) in all tubes at the optimal glucose : buffer ratio. On the other hand, the final $\mathrm{pH}$ value attained by suspensions from the other sugar media was not uniform, even at the optimal ratio, and it appeared that adaptation to glucose was incomplete (Table 5).

Most experiments were made on suspensions grown on LA and GA, but similar results were obtained when the organisms were grown on 'richer' media such as Hartley digest agar and the same medium + glucose. Hoogerheide (1940) showed that klebsiellas were less mucoid on nitrate media, and because of difficulties in spinning out the cells trials were made of suspensions from $\mathrm{LA}+1 \% \mathrm{KNO}_{3}$ and $\mathrm{LA}+1 \% \mathrm{KNO}_{3}+1 \%$ glucose. Table 6 shows that $\mathbf{L A}+\mathrm{KNO}_{3}$ gave suspensions that behaved as those from $\mathrm{LA}$, i.e. a $K$. aerogenes suspension maintained a low $\mathrm{pH}(\mathrm{MR}+)$ and did not produce a reversal of reaction; $\mathrm{LA}+\mathrm{KNO}_{3}+$ glucose gave suspensions that behaved like $\mathrm{GA}$, and the $\mathrm{pH}$ reverted to the alkaline side of methyl red $(\mathrm{MR}-)$.

\section{DISCUSSION}

It is hardly appropriate to call a test the ' $\mathrm{MR}$ ' when bromeresol purple may be used as an alternative indicator, but the application of the MR test to cultures of coliform bacteria is so well established that to change the name of the test would only cause confusion. The MR test merely indicates the $\mathrm{pH}$ value of a culture grown in a glucose phosphate peptone medium for an unspecified time at an unspecified temperature, and individual workers have set their own 
Table 5. The effect of adaptation to different sugars on $\mathrm{pH}$ value reached in the fermentation of glucose by Klebsiella aerogenes (NCTC 8348) and by Bacterium coli (NCTC 8169)

\begin{tabular}{|c|c|c|c|c|c|c|c|}
\hline & & & aero & & & act. col & \\
\hline & & & & ler conce & $\operatorname{tion}(p)$ & -8) & \\
\hline $\begin{array}{l}\text { Suspension } \\
\text { from growth }\end{array}$ & $\begin{array}{l}\text { concen- } \\
\text { tration }\end{array}$ & 0.1 M & $\begin{array}{c}0.05 \\
\text { value }\end{array}$ & $\begin{array}{l}0.025 \mathrm{M} \\
\mathrm{r} 24 \mathrm{hr} .\end{array}$ & $\begin{array}{l}0.1 \mathrm{M} \\
0 \text { (bron }\end{array}$ & $\begin{array}{l}0.05 \mathrm{M} \\
\text { esol pu }\end{array}$ & $\begin{array}{l}0.025 \mathrm{M} \\
\mathrm{e})\end{array}$ \\
\hline Lemco agar & 0.4 & $5 \cdot 2$ & $5 \cdot 2$ & $5 \cdot 2$ & $5 \cdot 2$ & $5 \cdot 2$ & $5 \cdot 2$ \\
\hline & $0 \cdot 2$ & $6 \cdot 0$ & $5 \cdot 2$ & $5 \cdot 2$ & $6 \cdot 0$ & $5 \cdot 2$ & $5 \cdot 2$ \\
\hline & $0 \cdot 1$ & $6 \cdot 4$ & $6 \cdot 2$ & $5 \cdot 2$ & $6 \cdot 4$ & $6 \cdot 2$ & $5 \cdot 2$ \\
\hline LA + glucose & $0 \cdot 4$ & $6 \cdot 2$ & $5 \cdot 8$ & $5 \cdot 2$ & $5 \cdot 2$ & $5 \cdot 2$ & $5 \cdot 2$ \\
\hline & $0 \cdot 2$ & $6 \cdot 4$ & $6 \cdot 2$ & $5 \cdot 8$ & $6 \cdot 0$ & $5 \cdot 2$ & $\mathbf{5 \cdot 2}$ \\
\hline & $0 \cdot 1$ & $6 \cdot 6$ & $6 \cdot 4$ & $6 \cdot 2$ & $6 \cdot 4$ & $6 \cdot 2$ & $5 \cdot 2$ \\
\hline LA + lactose & $0 \cdot 4$ & $5 \cdot 8$ & $5 \cdot 4$ & $5 \cdot 2$ & $5 \cdot 2$ & $5 \cdot 2$ & $5 \cdot 2$ \\
\hline & $0 \cdot 2$ & $6 \cdot 2$ & $5 \cdot 8$ & $5 \cdot 4$ & $6 \cdot 0$ & $\mathbf{5 \cdot 2}$ & $5 \cdot 2$ \\
\hline & $0 \cdot 1$ & $6 \cdot 4$ & $6 \cdot 2$ & $6 \cdot 0$ & $6 \cdot 4$ & $6 \cdot 2$ & $5 \cdot 2$ \\
\hline LA + maltose & $0 \cdot 4$ & $5 \cdot 2$ & $5 \cdot 2$ & $5 \cdot 2$ & $5 \cdot 2$ & $5 \cdot 2$ & $5 \cdot 2$ \\
\hline & $0 \cdot 2$ & $6 \cdot 2$ & $5 \cdot 4$ & $5 \cdot 2$ & $6 \cdot 2$ & $5 \cdot 2$ & $5 \cdot 2$ \\
\hline & $0 \cdot 1$ & $6 \cdot 4$ & $6 \cdot 2$ & $5 \cdot 8$ & $6 \cdot 4$ & $6 \cdot 4$ & $5 \cdot 2$ \\
\hline LA + mannitol & $0 \cdot 4$ & $5 \cdot 4$ & $5 \cdot 2$ & $5 \cdot 2$ & $5 \cdot 2$ & $\mathbf{5 \cdot 2}$ & $5 \cdot 2$ \\
\hline & $0 \cdot 2$ & $6 \cdot 2$ & $5 \cdot 8$ & $5 \cdot 2$ & $6 \cdot 2$ & $\mathbf{5 \cdot 2}$ & $5 \cdot 2$ \\
\hline & $0 \cdot 1$ & $6 \cdot 4$ & $6 \cdot 2$ & $6 \cdot 0$ & $6 \cdot 4$ & $6 \cdot 4$ & $5 \cdot 2$ \\
\hline
\end{tabular}

Table 6. Effect of groroth medium on $\mathrm{pH}$ value attained by Klebsiella aerogenes NCTC 243 in $24 \mathrm{hr}$. at optimal glucose : buffer ratio

Medium on which culture was grown

\begin{tabular}{|c|c|c|c|}
\hline $\begin{array}{c}\text { Glucose } \\
\text { concentration }\end{array}$ & $\mathbf{L A}+\mathrm{KNO}_{3}$ & $\begin{array}{l}\mathrm{LA}+\mathrm{KNO}_{3}+\text { glucose } \\
\text { pH value }\end{array}$ & GA \\
\hline 0.4 & $5 \cdot 0$ & 6.2 & 6.2 \\
\hline $0 \cdot 2$ & $5 \cdot 0$ & 6.2 & 6.2 \\
\hline $0 \cdot 1$ & $5 \cdot 4$ & $6 \cdot 2$ & 6.2 \\
\hline
\end{tabular}

time and temperature standards. Clark \& Lubs (1915) used $30^{\circ}$, incubated cultures for at least 3 days and recommended 5 days; in England the Ministry of Health method (Report, 1939) specified 3 days at $37^{\circ}$.

The indicator used has always been methyl red, but the critical range between 5.2 and 5.8 also lies at the acid end of the bromcresol purple range. 
Bromcresol purple has a distinct advantage over methyl red: it can be included in the microtest as an internal indicator and readings can be taken at any time; methyl red is rapidly decolorized by many coliform bacteria and can only be used at the conclusion of the test.

During the fermentation of glucose by bacterial cells the hydrogen-ion concentration depends primarily on the glucose : buffer ratio; for coliform bacteria in an excess of glucose the final $\mathrm{pH}$ value will be below 5 , but in excess of buffer it will be above 6. At the optimal glucose : buffer ratio suspensions of Bact. coli and $K$. aerogenes have different and distinctive effects; after $24 \mathrm{hr}$. Bact. coli shows a $\mathrm{pH}$ value of 5.0 or less, $K$. aerogenes 5.8 or more. These differences are not seen with cell suspensions from glucose-free media; glucose adaptation seems to be essential for a successful test of this type. The optimum glucose : buffer ratio generally applies between 0.1 and $0.8 \mathrm{M}$-glucose and 0.025 and $0.2 \mathrm{M}$-phosphate buffer, but a few strains of Bact. coli produced anomalous results with the lowest concentrations. Consequently, as a test for the characterization of coliform bacteria $0.2 \mathrm{M}$-glucose and $0.05 \mathrm{M}$-phosphate buffer or 0.4 M-glucose and 0.1 M-phosphate buffer are recommended; these concentrations maintain the optimal glucose : buffer ratio and give reasonably consistent results.

The translation of $\mathrm{pH}$ values into the MR test is largely arbitrary; at the extremes there is no difficulty in fixing positive and negative values; $I$ have used $\mathrm{pH} \mathrm{5.0}$ as $\mathrm{MR}+$ and $\mathrm{pH} \mathrm{5.8}$ as $\mathrm{MR}$-, with a doubtful or \pm range between these values. Harold (1936), on the other hand, suggested that the line of demarcation between MR + and MR - should be 5.8; at 5.8 and above the test is negative and at 5.6 and below it is positive. The advantage of eliminating the \pm or doubtful zone is obvious, but without it repeated tests may suggest an instability that is much less obvious with an intermediate zone.

The microtest developed is not readily applicable to routine work; unlike our other micromethods a degree of precision in the measurement of volumes is essential if the suspension : glucose : buffer ratios are to be maintained. A very dense suspension is necessary; suspensions adequate for other microtests may give irregular results in the Mr. The usual MR test on glucose peptone broth cultures is not without its difficulties, many of which can be overcome by the use of defined media (Clark \& Lubs, 1917; Richards \& Fouad, 1952). Suspensions in place of growing cultures, and glucose instead of a glucose-peptone mixture, simplify the conditions of the test but they do not remove all the sources of irregularity.

I wish to thank all those who supplied me with cultures of coliform bacteria, especially Drs Kauffmann, Richards and Windle Taylor.

\section{REFERENCES}

Clark, W. M. \& LuBs, H. A. (1915). The differentiation of bacteria of the colonaerogenes family by the use of indicators. J. infect. Dis. 17, 160.

Crark, W. M. \& LUBs, H. A. (1917). Improved chemical methods for differentiating bacteria of the coli-aerogenes family. J. biol. Chem. 30, 209. 
Clarke, P. H. \& Cowan, S. T. (1952). Biochemical methods for bacteriology. J. gen. Microbiol. 6, 187.

Cowan, S. T. (1953). Fermentations: biochemical micromethods for bacteriology. J. gen. Microbiol. 8, 391.

HAROLD, C. H. H. (1936). Rep. metrop. Wat. Bd. No. 30, pp. 97-8.

Hoogermeide, J. C. (1940). Studies on capsule formation. II. The influence of electrolytes on capsule formation by Klebsiella pneumoniae. J. Bact. 39, 649.

REPORT (1939). The bacteriological examination of water supplies. Rep. publ. Hlth med. Subj., Lond. no. 71.

Richards, T. \& Fouad, M. T. A. (1952). The use of glucose inorganic media in the classification of coli-aerogenes bacteria. Proc. Soc. appl. Bact. 15 (in the Press).

(Received 26 February 1953) 